\title{
Effect of aqueous extract of the leaves of Baccharis trimera on the proliferation of hepatocytes after partial hepatectomy in rats ${ }^{1}$
}

Sonia Oliveira Lima', Maria Bernadete Galrão de Almeida Figueiredo", Vanessa Rocha de Santana", Danillo Primo Andrade Santana"I, Matheus de Souza Nogueira'v, Erick Sobral Porto'v, Renata Lima Batalha de Andrade ${ }^{\mathrm{Iv}}$, Jessica Macêdo Santos ${ }^{\mathrm{IV}}$, Ricardo Luiz Cavalcanti de Albuquerque Junior', Juliana Cordeiro Cardosov

'PhD, Full Professor, Department of Morphology and Structural Biology, Research and Technology Institute, Universidade Tiradentes (UNIT), Aracaju-SE, Brazil. Scientific and intellectual content of the study; acquisition, analysis and interpretation of data; technical procedures; statistical analysis, manuscript writing, critical revision, final approval.

"Master, Department of Morphology and Structural Biology, Postgraduate Program in Health and Environment, UNIT, AracajuSE, Brazil. Scientific and intellectual content of the study; conception and design of the study; acquisition, analysis and interpretation of data; technical procedures; statistical analysis; manuscript preparation and writing.

"'Graduate student, Universidade Federal de Sergipe (UFS), Sao Cristovao-SE, Brazil. Acquisition of data, technical procedures, manuscript preparation.

IVGraduate student, UNIT, Aracaju-SE, Brazil. Acquisition of data, technical procedures, manuscript preparation.

vPhD, Postgraduate Program in Health and Environment, UNIT, Aracaju-SE, Brazil. Acquisition of data, technical procedures, manuscript preparation.

\section{Abstract}

Purpose: To evaluate the effect of aqueous extract of Baccharis trimera leaves on the proliferative capacity of the liver after partial hepatectomy (PH) in rats.

Methods: Twenty Wistar rats weighing between 300 and 450g were divided into two groups: control (HP) and test (HP100-rats that received the aqueous extract of Baccharis trimera for four days at a dose of $100 \mathrm{mg} / \mathrm{kg} / \mathrm{day})$. On the fifth day, animals from both groups underwent resection of $70 \%$ of the liver. Twenty-four hours later, they were sacrificed and the remnant liver was removed and prepared for studied through PCNA immunohistochemistry. Data analysis for comparison between the two groups was made through the non-parametric statistical test Mann-Whitney test.

Results: In all the animals studied was found most abundant nuclear immunostaining positive hepatocytes interlobular located in regions of the liver. Quantitative analysis of PCNA-positive cells revealed positivity rate significantly higher mean $(p=0.02)$ in HP100 group $(77.1 \pm 13.6)$ compared to the HP group ( $45.8 \pm 12.9)$.

Conclusion: DAdministration of aqueous extract of the leaves of Baccharis trimera $100 \mathrm{mg} / \mathrm{kg}$ of animal has a significant positive effect on liver regeneration in rats, 24 hours after hepatectomy (70\%).

Key words: Plants, Medicinal. Hepatectomy. Liver Regeneration. Baccharis. Rats. 


\section{- Introduction}

According to data from the World Health Organization (WHO), about $80 \%$ of the world's population uses medicinal plants, especially those from developing countries, and the lowincome population is the largest consumer ${ }^{1}$. Medicinal herbs are often the only source of therapeutic resources, because it is easier to grow them in backyards or find them for sale in popular fairs, than having access to a public health unit².

In Brazil, a large part of the population does not have access to industrialized medicines, a fact that strengthens the need for the use of herbal medicines in the healthcare system (SUS) ${ }^{3}$.

Although Brazil has an extremely rich flora and a tradition in the use of medicinal plants, most of the time, this is based only on popular knowledge, without any pre-clinical or clinical evidence ${ }^{4}$. In this context, knowing that the liver is an organ with high proliferative capacity that restores the lost hepatic mass through a global hyperplasia of the remaining parenchyma ${ }^{5}$, there is a great variety of substances tried in partially hepatectomized animals, in which evaluates their performances in the regenerative process ${ }^{6}$. The herbal products in nature appear as an important segment in this search ${ }^{7}$.

Among the various plants used as herbal medicines have the Baccharis trimera, popularly known as carqueja, found throughout South America. The first written record in Brazil the use of carqueja is from 1931, employed in form of infusion of leaves and branches for the treatment of male impotence and female sterility, attributing to it tonic, antipyretic and stomatal properties ${ }^{8}$. In the last decade, its medicinal use has increased, especially for liver problems solution, digestive disorders, diabetes, obesity and rheumatism ${ }^{9}$.

Due to the large number of liver diseases, the popular use of the carqueja and the lack of scientific studies on the effect of this plant on liver regeneration, the objective of this study was to evaluate the effect of the aqueous extracts of Baccharis trimera leaves on the proliferative capacity of the liver after extended hepatectomy in rats.

\section{Methods}

This research was in accordance with the ethical standards established by the Brazilian College of Animal experimentation (COBEA) and obtained approval from the Ethics Committee of the Universidade Tiradentes with the registration 17062005 .

The dried leaves of Baccharis trimera were acquired at the market Tales Ferraz, identified by Prof. Dr. Lauro Xavier, biologist and researcher at the Institute of technology and University research Tiradentes. These were weighed, crushed in an electric mill until a fine granulation powder was obtained. The extract was extracted from the powder, adding distilled water $(3: 10, \mathrm{p} / \mathrm{v})$ under constant stirring for 4 hours at $35^{\circ} \mathrm{C}$, then filtered $(\mathrm{pH}=6.0)$, lyophilized and stored at $5^{\circ} \mathrm{C}$. At the time of use, the extract was dissolved in distilled water at desired concentration.

In the four days preceding the surgical procedure, the 20 rats weighing 300 to 450 grams used in the study were kept in vivarium, with natural light-dark cycle, temperature and moisture environment and fed themselves with feed and water ad libitum. In this period, the study group corresponding to 10 rats (HP100) received $100 \mathrm{mg} / \mathrm{kg}$ aqueous extract of Baccharis trimera and the 10 animals in the control group (HP), water in a similar amount, without the plant extract. The administrations were made by gavage always at the same time, in one dose a day.

Surgical procedures were performed always at the same time, to avoid the influence of variations of the circadian cycle. The 
anesthetic used was diethyl ether because does not have potential hepatotoxic, such as gases halogenated anesthetics, and does not induce drug metabolism at the level of the hepatic microsomal system, such as barbiturates. After the trichotomy of the abdominal wall, was performed antisepsis with polyvinylpyrrolidone-iodine.

Access to the peritoneal cavity was made from a median laparotomy of about $4 \mathrm{~cm}$ from the xiphoid process in flow direction. In both groups, the left and middle lateral lobes of the liver were resected and their pedicles were ligated with cotton wool 3-0. This is equivalent to hepatectomy resection of approximately $70 \%$. The abdominal wall was closed in two planes with continuous sutures 4-0 monofilament nylon, the peritoneum and aponeurosis in a deep plane and the skin, in a superficial plane. After 24 hours a new laparotomy was performed using the same anesthetic technique, in order to remove the remaining liver, and the animals were sacrificed.

Silanized slide were used to prevent the detachment of the histological sections during staining. Obtained histological sections of $4 \mathrm{~mm}$ thickness tissue samples fixed in $10 \%$ formalin and embedded in paraffin. The specimens were processed by immunohistochemical technique by the method of Streptoavidin-biotin, using anti-PCNA monoclonal antibodies at 1:80 dilution (clone PC-10; DAKO A/S, Glostrup, Denmark). The sections were submitted to antigenic recovery through microwave treatment $(700 \mathrm{~W})$, with 3 cycle of 5 minutes each in $10 \mathrm{mM}$ citric acid (pH 6.0). After incubation with the primary and secondary antibodies, as well as with the StreptoavidinBiotin complex (SABC kit, DAKO A/S, Glostrup, Denmark), the sections were developed using $0.03 \%$ diaminobenzidine chromogen solution and Mayer hematoxylin counterstaining.

After the immunohistochemical labeling, a quantitative analysis of the expression of the protein PCNA was carried out, in which the number of immunolabellated cells in 1,000 randomly selected in the histological section was counted. Thus, for each case, were made 5 serial histological sections of $5 \mu \mathrm{m}$-thick, separated by a distance of $10 \mu \mathrm{m}$; in each slide were 10 photomicrographed histological fields ( $x 400$ magnification) selected by systematic randomization. In this way, the fields were selected from left to right and top to bottom; for each selected field followed two despised, until it reaches a total of 10 camps. The photomicrographed images were digitized using by Olympus $^{\circledR} 2000$ image capture software. They were considered positive PCNA, the hepatocytes with nucleus-restricted immunoreactivity, represented by brownish and/or yellowish staining, regardless of the staining intensity. For positive cells counts, was used UTHSCSA ImageTool ${ }^{\circledR}$ software version 3.0. Finally, a positivity index (PI) was obtained for each protein investigated using the formula described below:

$$
\frac{\mathrm{PI}=\text { number of positive cells } \times 100}{1.000 \text { cells randomly }}
$$

Data analysis was performed using the statistical analysis software SPSS 6.0, using the non-parametric Mann-Whitney statistical test to compare the two groups.

\section{Results}

In all animals studied, the PCNA was immunopositive, with scarce marking in the region surrounding the hepatic centrilobular vein and more abundant in the interlobular regions (Figure 1). The quantitative analysis of PCNA-positive cells revealed significantly higher mean PIs $(p=0.02)$ in the $\mathrm{P} 100$ group $(77.1 \pm 13.6)$ when compared to the HP group $(45.8 \pm 12.9)$ (Figure 2). 

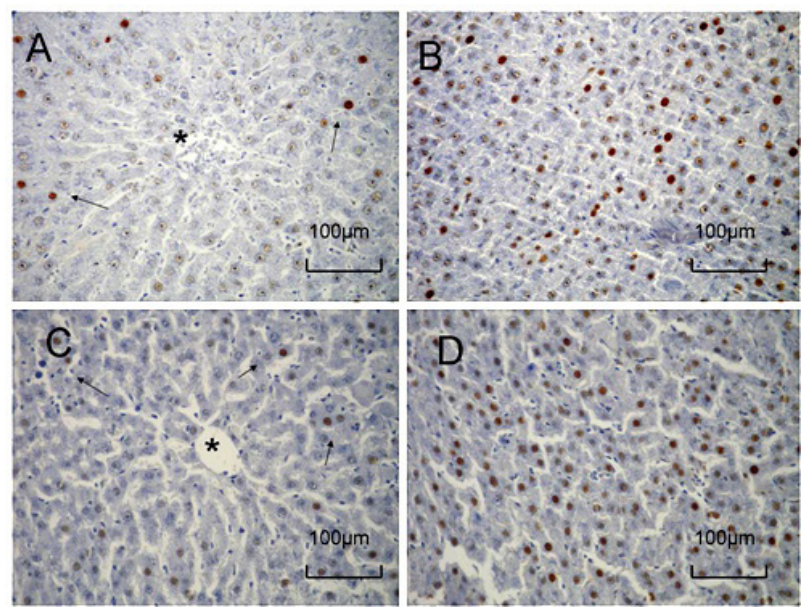

Figure 1 - Centrolobular regions and interlobular the control groups ( $A$ and $B$ ) and test ( $C$ and $D)$, showing positive nuclear immunostaining for PCNA. Note that the immunostained hepatocytes (arrows) are scarce in the region immediately surrounding the centrilobular vein $\left({ }^{*}\right)$ and interlobular abundant in the regions in both groups (SABC, $\times 200)$.

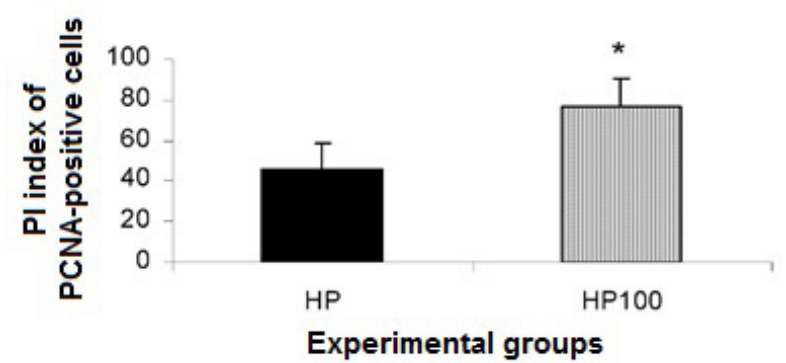

Figure 2 - Mean positivity index (PI) of PCNA-positive cells in the experimental groups. $\left({ }^{*}\right)$ Statistically significant difference $(p=0.02)$.

\section{- Discussion}

The brazilian population has become accustomed to the use of bitter plants when they have liver problems or related to digestion and the carqueja is one of the most used on this occasion ${ }^{10}$. The liver metabolizes substances absorbed by the digestive tract exposing itself to its components; so many plants used empirically in treating liver disorders have earned scientific proof. These may not produce effect, cause the benefit or, on the other hand, be toxic to this organ ${ }^{11}$.

The phytochemistry of the genus Baccharis has been extensively studied since the beginning of the twentieth century and currently more than 150 compounds have already been isolated and identified. The most common compounds in extract of Baccharis trimera are flavonoids and terpenoids, such as monoterpenes, sesquiterpenes, diterpenes and triterpenes ${ }^{12,13}$. Studies also show the presence of carquejol, clerodane derivatives, saponins and glycosides ${ }^{14}$. Several biological effects of these substances have been studied and many of these effects are attributed to flavonoids, such as anti-allergic activities, anticarcinogenic ${ }^{10}$, anti-inflammatory, antioxidant, hepatoprotective ${ }^{15}$ and relaxing the smooth muscles ${ }^{14}$.

In acute treatments with Baccharis trimera, there is no induction of signs of toxicity or mortality. In this sense, the daily oral administration, in rodents of both sexes, does notproducesignificant changes in hematological and biochemical parameters, except a reduction in liver enzymes alanine aminotransferase and aspartate aminotransferase ${ }^{16}$.

The restoration of liver mass after partial hepatectomy in humans appears to occur in two to three weeks, and is completed after three months ${ }^{17}$. Due to limitations in the use human liver for the study of regeneration, most of the information about this process has been obtained in vivo models with small animals (rats and mice) or using liver cells in culture (in vitro $)^{18}$. The liver proliferative process in rats process is similar to that of human liver proliferation, which justifies its widespread use in several areas of biomedical research (endocrine. Cellular, molecular and genetic) ${ }^{19}$. The main mechanism of hepatic mass recovery after subtotal resection is the proliferation of hepatocytes ${ }^{20}$.

In the study, rats were chosen because of the low acquisition and maintenance costs and 
because of their high resistance to infection and surgical trauma. Young animals were selected because age may compromise the post-partial hepatectomy and male regenerative response in order to attenuate the recognized influence of estrogens on liver regeneration ${ }^{21}$. To evaluate the proliferative activity of the hepatocyte PCNA was used because it is a nuclear protein that is associated with the cell cycle, to be essential for the synthesis of DNA and it is staining to function as a marker of the cells that are being reproduced.

The presence of immunopositive cells in a greater amount near the portal space checked in both groups studied corroborates the fact about $80 \%$ of the DNA synthesis occurs in the proximity of this space, indicating that the hepatocytes located in interlobular regions replicate the DNA early than those near the centrilobular vein ${ }^{22,23}$. It is likely that this finding is related to the fact that the factors involved in hepatic proliferation beat interlobular regions because they are carried primary by the portal vein.

Quantitative analysis of PCNA-positive cells revealed average IPs significantly higher ( $p=0.02$ ) in the group that used carqueja, which demonstrates the stimulatory effect of Baccharis trimera on rat liver regeneration. Similar findings were verified with the use of other plant extracts as Hyptis pectinata ${ }^{7}$, Sida cordifolia ${ }^{24}$, Hyptis fruticos ${ }^{11}$ and Peumus boldus $^{25}$. This positive effect on proliferation of hepatocytes may be related with the antioxidant property of flavonoids, since they regulate the activities of antioxidant enzymes, modulate nuclear receptors and act on gene expression ${ }^{26}$.

Several classic antioxidants have shown to be protective of hepatocytes against lipid peroxidation and inflammation, thus preventing the occurrence of hepatic necrosis ${ }^{27}$. In addition, it may be related to the relaxing vessel of the $B$. trimera extract, because with smooth muscles relaxation maybe be an increase in blood flow to the liver and thus a greater intake of substances involved in the proliferative process of hepatocyte ${ }^{14}$.

Research on liver regeneration and factors that can accelerate this process has a major relevance for the area of health ${ }^{5}$. Considering that when using adult rats, we can analyze the phenomenon of liver regeneration in the absence of growth stimuli of the organism, excluding the general and specific mechanisms that could be in effect inducing cell division activity in various tissues and organs ${ }^{28}$. This pioneering study, therefore deserves to be complemented with the intention of identifying the active principles present in Baccharis trimera, the mechanisms involved in the stimulation of hepatocyte proliferation, incorporate a minimum of two independent markers from hepatocyte proliferation. Lastly, changes in hematological, biochemical parameters and liver functions should be evaluated.

\section{Conclusions}

The administration during the previous 4 days of $70 \%$ hepatectomy in rats of the crude aqueous extract of lyophilized from leaves of Baccharis trimera, at the concentration of $100 \mathrm{mg} / \mathrm{kg}$ of animal, exerts significant positive effect on the liver proliferation of rats, 24 hours after hepatectomy (70\%).

\section{References}

1. Machado HL, Moura VL, Gouveia NM, Costa GA, Espindola FS, Botelho FV. Research and extension activities in herbal medicine developed by Rede FitoCerrado: rational use of medicinal plants by the elderly in Uberlândia-MG. Rev Bras Plantas Med. 2014;16(3): 527-33. doi: 10.1590/1983084X/13_072.

2. Espinosa OL, Calabuch HR, Espinosa IL. Knowledge and opinions on medicinal plants and herbal drugs of the physicians in La Sierpe and Sancti Spiritus municipalities. Rev Cubana Plant Med. 2008;13(1):1-10. 
3. Linard AT, Barros RM, Sousa JA, Leite RS. Epidemiology of bee stings in Campina Grande, Paraíba state, Northeastern Brazil. J Venom Anim Toxins Incl Trop Dis. 2014 Apr 2;20:13. doi: 10.1186/1678-9199-20-13.

4. Ferreira ASP. Hepatotoxicidade: há evidências para o uso de hepatoprotetores? Rev Suplemento Hepatotoxicidade. 2011;30(1):39-40.

5. Biondo-Simões MLP, Matias F, Martone D, Barbosa RF, Ogawa GH. Influência da glutamina na regeneração hepática. Rev Med. 2007;86(4):219-23. doi: 10.11606/ issn.1679-9836.v86i4p219-221.

6. Silva RM, Malafaia O, Torres OJM, Czeczko NG, Marinho Junior $\mathrm{CH}$, Kozlowski RK. Avaliação da regeneração hepática com dieta suplementada com ácidos graxos ômega-3: estudo experimental em ratos. Rev Col Bras Cir. 2015 Nov-Dec;42(6):393-7. doi: 10.1590/0100-69912015006008.

7. Silva $A B L$, Dias KS, Marques MS, Menezes IAC, Santos TC, Mello ICM, Lisboa ACCD, Cavalcanti SCH, Marçal RM, Antoniolli AR. Evaluation of the analgesic effect and acute toxicity of the aqueous extract of Hyptis fruticosa (Salmz. ex Benth.). Rev Bras Farmacogn. 2006;16(4):475-9. doi: 10.1590/ S0102-695X2006000400006.

8. Agra MF, Silva KN, Basílio IJL, Freitas PF, Barbosa-Filho JM. Survey of medicinal plants used in the region Northeast of Brazil. Rev Bras Farmacogn. 2008;18(3):472-508. doi: 10.1590/S0102-695X2008000300023.

9. Auler NMF, Battistin A, Reis MS. Number of chromosomes, microsporogenesis and pollen viability in populations of carqueja [Baccharis trimera (Less.) DC.] from Rio Grande do Sul and Santa Catarina. Rev Bras Plantas Med. 2006;8(2):55-63.

10.Rodrigues CR, Dias JH, de Mello RN, Richter MF, Picada JN, Ferraz AB. Genotoxic and antigenotoxic properties of Baccharis trimera in mice. J Ethnopharmacol. 2009 Aug 17;125(1):97-101. doi: 10.1016/j. jep.2009.06.006.

11.Lima SO, Viana Lda C, Santana FR, Zucoloto $\mathrm{S}$, Albuquerque Junior RL, Gomes $\mathrm{MZ}$. Proliferative effect of aqueous extract of
Hyptis fructicosa on liver regeneration after partial hepatectomy in rats. Acta Cir Bras. 2012 Jan;27(1):71-5. PMID: 22159442.

12.Verdi LG, Brighente IMC, Pizzolatti MG. The Baccharis genus (Asteraceae): chemical, economic and biological aspects. Química Nova. 2005;28(1):85-94. doi: 10.1590/S010040422005000100017.

13. Moreira FPM, Coutinho V, Montanher ABP, Caro MSB, Brighente IMC, Pizzolatti MG. Flavonoids and triterpenes from Baccharis pseudotenuifolia - Bioactivity on Artemia salina. Química Nova. 2003;26(3):309-11. doi: 10.1590/S0100-40422003000300004.

14.deOliveira CB, ComunelloLN, MacielES, Giubel SR, Bruno AN, Chiela EC, Lenz G, Gnoatto SC, Buffon A, Gosmann $G$. The inhibitory effects of phenolic and terpenoid compounds from Baccharis trimera in Siha cells: differences in their activity and mechanism of action. Molecules. 2013 Sep 9;18(9):11022-32. doi: 10.3390/molecules180911022.

15.Pádua BdaC, Rossoni Júnior JV, Magalhães CL, Chaves MM, Silva ME, Pedrosa ML, de Souza GH, Brandão GC, Rodrigues IV, Lima WG, Costa DC. Protective effect of Baccharis trimera extract on acute hepatic injury in a model of inflammation induced by acetaminophen. Mediators Inflamm. 2014;2014:196598. doi: 10.1155/2014/196598.

16.da Silva ARH, Reginato FZ, Guex CG, Figueredo KC, da C Araldi IC, de Freitas RB, Boligon AA, Athayde ML, Mazzanti CM, Hübscher $\mathrm{GH}$, de $\mathrm{F}$ Bauermann L. Acute and sub-chronic (28 days) oral toxicity of tincture Baccharis trimera (Less) Backer in male and female rodent animals. Regul Toxicol Pharmacol. 2016 Feb;74:170-7. doi: 10.1016/j.yrtph.2015.10.024.

17.Khan AZ, Mudan SS. Liver regeneration:mechanisms, mysteries and more. ANZ J Surg. 2007 Jan-Feb;77(1-2):9-14. doi: 10.1111/j.1445-2197.2006.03981.x.

18.Koniaris LG, Mckillop I, Scwartz SI, Zimmers TA. Liver regeneration. J Am Coll Surg. 2003;197(4):634-48. doi: 10.1016/S10727515(03)00374-0.

19.Rosal MA, Gonçalves WJ, Alves MTS, Baracat EC, Lima GR. Histopathological and 
immunohistochemical analysis (proliferating cell nuclear antigen) of patients with invasive cervical carcinoma before and after radiotherapy and surgery. Rev Assoc Med Bras (1992). 2002 Jan-Mar;48(1):32-5. PMID: 12185633.

20.El'chaninov AV, FatkhudinovTKh, Kananykhina EY, Usman NY, Arutyunyan IV, Makarov AV, Sukhikh GT. Role of progenitor cells in liver regeneration after subtotal resection. Bull Exp Biol Med. 2016 May;161(1):155-61. doi: 10.1007/s10517-016-3367-5.

21.Francavilla A, Barone $M$, Todo S, Zeng QH, Porter KA, Starzl TE. Augmentation of rat liver regeneration by FK506 compared with cyclosporin. Lancet. 1989 Nov 25;2(8674):1248-9. PMID: 2479802.

22.Ramalho FS, Ramalho LNZ, Zucoloto S, Silva Jr OC. Regeneração hepática - Algumas definições num universo de incertezas. Acta Cir Bras. 1993;8 (4):177-89.

23.MiChalopoulos GK, De Frances MC. Liver regeneration. Science. 1997 Apr 4;276(5309):60-6. PMID: 9082986.

24.Silva RL, Melo GB, Antoniolli AR, Lima SO, Melo VA, Ramalho FS, Ramalho LNZ, Zucoloto $S$, Silva Júnior OC. Effect of the aqueous extract of Hyptis pectinata on hepatocyte proliferation after partial hepatectomy. Acta Cir Bras. 2002;17(3):101-5. doi: 10.1590/ S0102-86502002000900021.

25.Figueiredo MB, Santana VR, Nardelli MJ,
Nogueira MS, Azevedo DX, Santana DP, Figueiredo AG, Duarte ÍX, Albuquerque RL Junior, Lima SO. The effect of the aqueous extract Peumus boldus on the proliferation of hepatocytes and liver function in rats submitted to expanded hepatectomy. Acta Cir Bras. 2016 Sep;31(9):608-14. doi: 10.1590/S0102-865020160090000006.

26. Melo JU, Melo RB, Santos JM, Campos Júnior MM, Guimarães SB, Vasconcelos PR. Effects of bioflavonoid ternatin on liver regeneration and oxidative stress in rats. Acta Cir Bras. 2013 Jun;28(6):435-40. PMID: 23743681.

27.Ahmad F, Tabassum N. Preliminary phytochemical, acute oral toxicity and antihepatotoxic study of roots of Paeonia officinalis Linn. Preliminary phytochemical, acute oral toxicity and antihepatotoxic study of roots of Paeonia officinalis Linn. Asian Pac J Trop Biomed. 2013 Jan;3(1):64-8. doi: 10.1016/S2221-1691(13)60025-8.

28.Toderke EL, Baretta GAP, Gama Filho OP, Matias JEF. Sirolimus influence on hepatectomy-induced liver regeneration in rats. Rev Col Bras Cir. 2014:41(3):203-7. PMID: 25140653.

\section{- Acknowledgement}

To Sonia Maria Bismarck dos Santos for the support during the execution of surgical procedure in rats.

\section{Correspondence:}

Sonia Oliveira Lima

Avenida Beira Mar, 1044/602

49020-010 Aracaju-SE Brasil

Tel.: (55 79)3216-4800

sonia.sol@ibest.com.br

m4theus@hotmail.com

Received: Dec 19, 2016

Review: Feb 16, 2017

Accepted: March 20, 2017
Conflict of interest: none

Financial source: none
${ }^{1}$ Research performed at Bio Laboratory
of Morphology and Structural Biology
(LMBE), Research and Technology Institute,
Universidade Tiradentes (UNIT), Aracaju-SE,
Brazil. 